\title{
ATTITUDES OF SECONDARY SCHOOL LEAVERS TOWARDS MANUAL WORK: IMPLICATIONS FOR YOUTH EMPLOYMENT IN BOTSWANA
}

\section{Kwaku Osei-Hwedie, Diana Kgwatalala}

\section{INTRODUCTION}

The importance of generating opportunities for citizens to participate in the development of self and country cannot be exaggerated. Employment is usually the main way in which people contribute to the economic growth of a country. Work is an essential part of human life that helps in determining, among other things, one's social status. Therefore, it is important that at a certain stage in life one should acquire a job. The International Labour Organisation (ILO) (2008) notes that at some point in their lives youths will enter the world of work as a path toward social integration and as a means to earn an income. Youth unemployment has progressively emerged as a major problem in many developing countries and the world at large. For many youths entry into the labour market comes directly after completing school, depending on the schools' exit points of the particular country. Botswana's Secondary School education, which is completed in five years, has two exit points. The Junior Certificate (JC) runs for three years, and those who do not pass exit after Form 3. The Botswana General Certificate of Secondary Education (BGCSE) takes two years and the exit point is Form 5 for those who do not qualify to proceed to the tertiary level.

\section{YOUTH UNEMPLOYMENT}

The ILO (2009) suggests that at the end of 2008 working poverty, vulnerable employment and unemployment were beginning to rise as a result of the global financial crisis. Enterprises stopped hiring and many workers were laid off. More disheartening is the fact that the ILO (2009) adds that the longer people stay out of work, the more their "employability" deteriorates, making it progressively harder to get back into work. This is especially worrying for young workers, who may get trapped into a lifetime of weak attachment to the labour market, alternating between low-paid, insecure work and outright unemployment. The ILO (2004) shows that, while youths represent $25 \%$ of the working-age population between 15 and 64 , they made up as much as $47 \%$ of the total of 186 million people out of work worldwide in 2003. A 2006 report by the ILO notes that youths are three times more likely to be unemployed than adults, and that the relative disadvantage is more pronounced in developing countries.

Verma (2004) points out that youth unemployment in 2004 was worse in North Africa, with a youth unemployment rate of 25.6\%, and 21\% in Sub-Saharan Africa. The ILO (2008) paints a grim picture of the future for Sub-Saharan Africa by noting that sub-Saharan African youths remain among the most challenged in the world when it comes to securing decent and productive employment. The ILO (2008) indicates that the number of unemployed youths rose by $13.6 \%$ between 1997 and 2007, from 63 million to 71 million. The ILO (2008) further notes that youths make up $40.2 \%$ of the world's total unemployed, although they comprise only $24.7 \%$ of the total working-age population. The following year the ILO (2009) showed that in 2008 youth unemployment rose again to 76 million. The current economic meltdown makes the youth unemployment situation all the more worrisome because many countries, more especially developing countries, had failed to adequately address the problem of youth unemployment during the time when their economies were more stable. 
Botswana's Household Income and Expenditure Survey (2002/3) points out that in 2002-2003 the unemployment rate in Botswana stood at $23.8 \%$ with the highest rates among the age groups 15-19 and 20-24. Siphambe (2003) noted that in Botswana the 15-19 age group completed either junior or senior secondary school education and had no skills or proper qualifications that would render them useful to the labour market. He indicated further that unemployment, in relation to educational attainment, is highest (38\%) among people with a Form 1 to Form 3 level of education. Siphambe (2003) showed that in Botswana the unemployment rate was at $21.6 \%$ in 1994 and declined to $20.8 \%$ in 1998 and was estimated at $19.5 \%$ in 2001. According to Central Statistics Office (2008), the 2005/6 labour force survey puts Botswana's unemployment rate at $17.5 \%$. The survey also indicates that the most affected were the 15-19 and the 20-24 age groups, with $26.7 \%$ and $34.9 \%$ unemployment rates respectively. Furthermore, most of the unemployed are found in urban centres (57.2\%). The emerging trend indicates that even though unemployment in Botswana is declining, the age groups 15-19 and 20-24 are consistently affected by the problem most significantly.

Many reasons account for why the youth are consistently affected by the problem of unemployment. Poor economic growth in many regions of the world has caused severe employment problems for youths, who are the most vulnerable group of workers. A continuous and fast pace of change in the demand for skills increases the emphasis on training and lifelong learning to raise employability and improve access to employment. This change, in turn, puts more pressure on youths, who often find themselves lacking the necessary skills required for available jobs. The labour market also has barriers. These include poor growth, age discrimination, insufficient access to fundamental education and rapid economic changes. The United Nations Economic Commission for Africa (UNECA) (2002) states that Africa's underdevelopment, characterised by high rates of population growth, sluggish or stagnant economies, a small private sector, low literacy and numeracy rates, and poor-quality education, is the driving force behind youth unemployment.

UNECA (2002) notes that many youths lack the necessary educational qualifications required for most of the white-collar jobs. In addition, the labour market is often saturated and there are negative attitudes towards some of the available jobs. Young people find themselves ineligible for most jobs, even unskilled occupations, because sometimes they are either too young, or lack the experience required by employers. UNECA (2002) alludes to the fact that young people often have no job histories and no job-specific skills. At the same time many of them have serious reservations about jobs associated with low wages.

Skans (2004) points out that unemployment has a negative impact on the future of the labour market, because of the work experience forgone during the spell of unemployment, or perhaps more seriously because of the assumption that if people's skills are not used, they deteriorate. It is therefore possible that the market value of the skills acquired during the secondary school years may depreciate rapidly unless the skills are used. This situation may be aggravated by the fact that a large number of school leavers fail their exams. Thus they cannot proceed with their education and at the same time many of them are not absorbed by the labour market.

Available data indicate that for the past several years far less than half of the Form $5 \mathrm{~s}$ who sat for the BGCSE passed with grade C or better. Thus from 2002 to 2006 far less than half of the students who sat for the BGCSE exam in all Botswana senior secondary schools were awarded grades $\mathrm{C}$ or better. In 2002 the pass rate was 36.38\%; 2003, 39.18\%; 2004, 38.44\%; 2005, $38.81 \%$; and in 2006, 41.59\%. For 2006 the rate for the school with the highest pass rate was $65.17 \%$, while for the bottom school it was only $26 \%$ of the students who got grade $\mathrm{C}$ or better 
(The Voice, 23 February 2007). Furthermore, Botswana Daily News (18 February 2005) indicated that 168.427 students had registered for BGCSE examinations in 2005. This suggests that only $38.81 \%$ of the total managed to get grade $\mathrm{C}$ or better. In the light of these results, one may wonder what happens to the rest of the students who do not pass. Some are able to pay their tuition and re-take for the exam, or enrol in private schools. However, many do not have such an opportunity and may be left with nothing to do except sit at home.

Of great concern is the fact that the youths who are hardest hit by the problem of unemployment seem to shun certain jobs. A Member of Parliament, Lesego Motsumi, observes that in general, Batswana tend to shun jobs such as domestic chores, yet the country is faced with the problem of unemployment (Daily News, 7 February 2003). Furthermore, Mukamugambira and Osei-Hwedie (2007) identify negative attitudes towards manual work among youths as one of the factors contributing to youth unemployment in Botswana. The youth seem not to realize that manual work can provide them with the means of survival. Manual work is defined in this paper as the production of material goods through work activities that are predominantly physical in nature. Such activities may be carried out in factories or outdoors. Sometimes this is referred to as blue collar work (BNET, 2010).

Over the years many people have developed negative attitudes towards manual work. The reasons for this include the low social status and poor working conditions attached to such work. It is also asserted that firms recruiting school leavers to unskilled jobs are usually seeking cheap, and often temporary, labour. Because of the negative factors associated with manual work, the threat of unemployment does not always prevent young unskilled workers from remaining unemployed. Maintaining self-respect and status in the eyes of their peers and society sometimes makes young people not to take what they refer to as "trash jobs" (Smith, 2002). This study therefore examined the attitudes towards manual work of secondary school leavers, Form $3 \mathrm{~s}$ and Form $5 \mathrm{~s}$ who were about to complete school, and the factors that facilitate such attitudes. Mukamugambira and Osei-Hwedie (2007) investigated the attitudes of Botswana youths who were already engaged in the construction, domestic and agricultural sectors towards manual work. The current study examines the attitudes of students towards manual work before they leave school.

\section{THEORETICAL AND CONCEPTUAL BASIS}

A number of theories try to explain the development of people's behaviour and attitudes towards certain things in their environment. For the purpose of this paper, the theory of reasoned action by Fishbein and Ajzen (1975) and Ajzen and Fishbein (1980) was used (see also Hale, Householder \& Green, 2003; Miller, 2005). This theory holds that attitudes stem from the information an individual has about a given object. The theory assumes that humans are rational and have the ability to process and use the available information to arrive at a reasonable behavioural decision. The theory also holds that attitudes are determined by beliefs that result from information one has about a particular object. For each belief, outcomes are analysed, weighed up and then action is taken. Outcomes are usually based on the individual's evaluation of the information about the object and the strength of the belief. The outcomes of what individuals believe in differ from one individual to another, depending on the environmental context.

In the light of this theory, it may be said that youths' attitudes towards manual work are a result of the information available to them. They are able to access and evaluate the information and form an opinion. Whether to engage in manual work or not depends on how much they believe 
in the information they have. The theory also indicates that the social environment plays a very important role in shaping the attitudes of youths towards manual work. For example, societal beliefs about manual work are passed on to the youths. The views of peers, family and friends influence the youths' perception of manual work, to the extent that some of them may choose to remain unemployed than to engage in manual work.

\section{HISTORY OF MANUAL WORK}

Manual work has always carried with it different perceptions and attitudes from time immemorial. Hill (1996) notes that the Hebrew belief system viewed work as a curse devised by God explicitly to punish the disobedience and ingratitude of Adam and Eve. The Greeks, like the Hebrews, also regarded work as a curse. To them, manual labour was for slaves. The Romans, who adopted much of their belief system from the Greeks, also held manual labour in low regard. Plato recognised the notion of the division of labour, separating it into categories of rich and poor, and then into different kinds of work. Aristotle supported ownership of private property and wealth. He viewed work as a corrupt waste of time that makes a citizen's pursuit of virtue more difficult (Hill, 1996).

Woven into the perceptions and attitudes of Greeks, Romans, Hebrews and some of the great philosophers towards manual work is its association with social status. The work people did became the criterion for determining their social status. Plato and Aristotle made it clear that the reason why the majority laboured was so that that the minority and the elite might engage in the pure exercise of the mind, art, philosophy and politics. Thus at the time of Plato and Aristotle, it was realized that work was not only necessary for the satisfaction of material needs, but that it also defined one's social status in society. Division of labour was a strategy to place the burden of production on one group of people who were also accorded low social status (Hill, 1996). The belief and attitudes of ancient times have persisted into contemporary society. Manual work is still looked down upon, despite the realization among many people that there is nothing wrong with it and, above all, that it is necessary.

\section{THE VALUE OF, AND ATTITUDES TOWARDS, WORK}

Different values are attached to work by individuals depending on the society they belong to. HELPR System (2004) asserts that people work for many reasons, but usually it is to bring meaning and satisfaction to their lives, as well as benefits to society in general. People's attitudes towards work vary from one society to another, and depend on the meaning and value attached to the type of work (Osei-Hwedie, Mufune \& Mwansa, 1991). For example, people may have a positive attitude towards manual work because of the social status and the prestige it brings. Kiuranov (1982) surveyed the attitudes to work of three generations in Bulgaria grandparents, parents and their children. The results indicate that for grandparents work was the real meaning of life; for parents it was better to work for nothing than be idle; for their children, it was work, yes, but what kind? This shows that attitudes to work may change from generation to generation depending on which values are emphasised at that particular time. Kiuranov (1982) goes on to assert that the contemporary generation manifests positive attitudes to work, but has important concerns as to what kind of work has to be performed, and what the content of the work is.

A study in Australia found out that the community had negative attitudes towards manual work, placed a low value on it, and considered it as a lower-class option (Lewis, 1992). Lloyd (1999) found that all the young men he interviewed made a very strong distinction between a "career job" and a "crap job". The common views held about "crap jobs" were that such jobs were very 
easy to find and to leave, never paid well, and had poor working conditions and insecure work environments. It seems that such conditions and other aspects of manual work are some of the factors contributing to its low social status and negative attitudes towards it. In their study in Zambia, Osei-Hwedie et al. (1991) found that white-collar jobs had more prestige than nonwhite-collar jobs, and the majority of Zambian youths in the study preferred work with more responsibility and authority.

\section{FACTORS THAT INFLUENCE CAREER CHOICES, WORK PREFERENCES AND WORK VALUE}

Authors such as Osei-Hwedie et al. (1991), Romo (1998), Karlsen (2001), Bergmann (2002) and Melzer (2003) identify factors that influence career choices, work preferences and work value. Some of the factors influencing one's attitude to a particular job include level of education, parents' occupation and social status. For example, Osei-Hwedie et al. (1991) note that with regards to education, respondents with primary education selected agriculture as their first-choice occupation, while those with no education chose service. Respondents with secondary and post-secondary education preferred administrative/managerial/professional and technical jobs. This indicates that the level of education may influence one's choice and preference of work. The more educated one is, the greater the preference for positions of power and responsibilities.

Students' performance at school also seems to influence their career choices and work preferences. In a study done in Australia over $25 \%$ of students who intended to enter the labour market full time expected to do poorly in their year 11 studies. Students with performing well at school were most likely to agree that their investment in education would be worthwhile (Australian National Board of Employment, Education and Training, 1995). Romo (1998) notes that when Latinos do not see any possibility of doing well in school or pursuing postsecondary education or a career, they often leave school and start a family. He adds that even with families' encouragement, poor performance at school can pressure students into dropping out and being steered into jobs with little income.

In many countries schools are blamed for aggravating, if not causing, school leavers' unemployment problems. This is because schools are seen as being too academic and not preparing children for productive life (Bergmann, 2002). The Society for the Integrated Development of Himalayas (SIDH) (2000) accuses the educational system of creating a false distinction between superior and inferior work, and for propagating the myth that superior work is that which does not require working with one's hands. It is also seen as a system that creates unreal and undesirable aspirations towards certain kinds of occupations. Formal education produces aspirations for desk jobs and the youths are consequently alienated from their traditional occupations and cultural contexts. Instead of returning to, and improving on, the traditional vocations such as farming, brick laying, and cattle rearing, educated youth see them as being inferior, and will not return to them even when they fail to get the desired jobs (SIDH, 2000).

Studies indicate that gender also influences individual's work values and preferences. Gender attitudes influence whether girls will pursue stereotypical vocations and familial paths or seek higher education and careers. Karlsen (2001) found out that job-seeking choices made by girls tend to be more influenced by altruistic motives more than those of boys, and that girls are more inclined to have their choices influenced by a desire to help others, work with people and be closer to family. These attitudes also extend into schools. Clark and Page (2002) note that 
both boys and girls are affected by narrow gender-based patterns of subject choices. Girls' patterns of choice reflect a strong interest in interpersonal relationships, care for others and human problems. Boys are particularly reluctant to participate in those curriculum areas that are seen as feminine. Neither girls nor boys readily and routinely cross traditional gender lines in jobs or training activities.

Melzer (2003) concludes that society's expectations of the role of men in the work world may mean that a man is ridiculed by society for his decision to do "women's work". It is about societal expectations of what is appropriate for men and women. More often than not, women who do manual work are considered to be abnormal in some way because they are engaged in what has been labelled as "men's work". Gender stereotypes do not only affect the older generation, but are also found in the school setting where girls take subjects that are regarded as feminine (e.g. home economics), while boys choose subjects which are masculine (e.g. design and technology). Siphambe (2003) notes that in Botswana females are less represented (8\%) in plant and machine operations and assemblers. He indicates that the distribution of employees by occupation is still reflective of the occupational segregation that is typical of most developing countries, where women tend to be crowded into jobs labelled as "feminine".

The ILO (2004) asserts that the intellectual, moral and social development of children is shaped by their families. They are also heavily influenced by their peers, who form a network of social support and contribute to the formation of attitudes and values. Through their actions and encouraging or discouraging comments, family members also influence career choice and work preferences. Laughlin and Barlin (2001) note that socialisation into the world of work does not begin when individuals assume their first full-time job. As children watch and listen to their parents and others, they learn about the world of paid employment.

\section{METHODOLOGY}

The study adopted a descriptive design. Both quantitative and qualitative methods were employed to collect the data. The study was carried out in Gaborone (capital city), Moshupa and Lentsweletau (villages) in 2006. The sample was derived from two public schools from Gaborone (a junior and senior secondary school), a senior secondary school in Moshupa, and a junior secondary school in Lentsweletau. The schools in Gaborone were selected using the lottery method from a total of 18 schools. Moshupa Senior Secondary and Lentsweletau Junior Secondary were selected purposively to contrast with schools in Gaborone. These were the only schools in those villages. The secondary school leavers category includes the Form $3 \mathrm{~s}$ and Form 5s. These two Forms were chosen because in the Botswana context they are the exit points for the Junior Certificate (JC) and the Botswana General Certificate of Secondary Education (BGCSE) respectively. At these points the secondary school leaver may decide to proceed with further studies or not. The population of secondary school leavers from which the study sample was drawn consisted of 422 Form 3s and 1378 Form 5s. Probability design was used to select a sample size of 200. Hundred students were selected from the schools in Gaborone and 50 each from Moshupa and Lentsweletau. In all, four focus group discussions of 10-15 males and females were held.

\section{FINDINGS AND DISCUSSION}

\section{BIOGRAPHICAL DATA OF RESPONDENTS}

The ages of the respondents range from 15 to 20 years; 50 (25\%) students were 18 years old; 48 (29\%), 16 years; 39 (19.5\%), 17 years; 37 (18.5\%), 15 years; $25(12.5 \%), 19$ years; and 1 $(0.5 \%), 20$ years. The mean age of the respondents was 17 years (Table 1$) .50 \%$ of the sample 
were from Gaborone, while the remaining 50\% were from Moshupa and Lentsweletau. These areas and the sample were deliberately selected to get a representation of both rural and urban secondary school leavers. With respect to gender, the sample was also deliberately selected to reflect a gender balance. Thus 100 (50\%) males and 100 (50\%) females were purposely selected.

\section{TABLE 1}

AGE OF RESPONDENTS

\begin{tabular}{|l|c|c|}
\hline Age & No & \% \\
\hline 15 & 37 & 18.5 \\
\hline 16 & 48 & 24.0 \\
\hline 17 & 39 & 19.5 \\
\hline 18 & 50 & 25.0 \\
\hline 19 & 25 & 12.5 \\
\hline 20 & 1 & 0.5 \\
\hline $\mathbf{2 0 0}$ & $\mathbf{2 0 0}$ & $\mathbf{1 0 0}$ \\
\hline
\end{tabular}

\section{JOB- AND CAREER-RELATED ISSUES}

A large majority $(198,99 \%)$ of the respondents indicated that they view work as an important part of life, while an insignificant number $(2,1 \%)$ said work was not important. In relation to job aspirations after completing school, 60 (30\%) of the respondents chose service jobs; 52 (26\%) professional; 35 (18\%) managerial; 28 (14\%) agricultural; 21 (10\%) entertainment; and $4(2 \%)$ construction (Table 2$)$.

TABLE 2

\section{RESPONDENTS' JOB ASPIRATIONS AFTER COMPLETING SCHOOL}

\begin{tabular}{|l|c|c|}
\hline Type of Job & No. & \% \\
\hline Service & 60 & 30.0 \\
\hline Professional & 52 & 26.0 \\
\hline Managerial & 35 & 17.5 \\
\hline Agricultural & 38 & 14.0 \\
\hline Entertainment & 21 & 10.5 \\
\hline Construction & 4 & 2.0 \\
\hline Total & $\mathbf{2 0 0}$ & $\mathbf{1 0 0}$ \\
\hline
\end{tabular}

As to what would influence the respondent's choice of work, a large number (158, 79\%) indicated salary; $15(8 \%)$ said they would be influenced by job satisfaction; $4(2 \%)$ by job security; and $23(11 \%)$ by the ability to do the job. This means that for the respondents, how much a job pays may play an important role in their choice of work. 
TABLE 3

REASONS FOR RESPONDENTS' CHOICE OF JOBS

\begin{tabular}{|l|c|c|}
\hline Reasons & No. & \% \\
\hline Salary & 158 & 79 \\
\hline Ability to do the work & 23 & 11 \\
\hline Job satisfaction & 15 & 8 \\
\hline Job security & 4 & 2 \\
\hline Total & $\mathbf{2 0 0}$ & $\mathbf{1 0 0}$ \\
\hline
\end{tabular}

Asked why they would get a job, 90 (45\%) of the respondents indicated that they would work to support their families; $48(24 \%)$ would work to get all the things they wanted; 9 (4\%) would work to avoid staying idle; and $53(27 \%)$ would work to get recognition from peers and family (Table 4).

TABLE 4

RESPONDENTS' REASONS FOR WORKING

\begin{tabular}{|l|c|c|}
\hline Reason & No & \% \\
\hline Support family & 90 & 45 \\
\hline Get recognition from peers & 53 & 27 \\
\hline Get things wanted in life & 48 & 24 \\
\hline Avoid staying idle & 9 & 4 \\
\hline Total & $\mathbf{2 0 0}$ & $\mathbf{1 0 0}$ \\
\hline
\end{tabular}

In relation to the issue of how well respondents felt that school had prepared them for work, Table 5a shows that the majority $(128,64 \%)$ believe school prepared them adequately for work. With respect to location (Table $5 b$ ), the majority of respondents in both Gaborone $(63 \%)$ and Lentsweletau (76\%) agreed that school prepared them adequately for work. Only in Moshupa did a minority of respondents (48\%) disagree. Thus students in both urban and rural areas believe they receive the necessary preparation for work from school. However, this perception may be unrealistic. For example, in Botswana youths are worst affected by the problem of unemployment. This is confirmed by Siphambe (2003), who notes that unemployment is highest in the 15- to 19-year-old age group, who are recent school leavers, with no skills or proper qualifications. They often find themselves ineligible for the majority of the advertised jobs, even unskilled occupations. This is because they are too young, or lack the experience demanded by employers. Thus, the perception of the respondents about being adequately prepared for work may not be in line with that of employers about school leavers' suitability for employment. 
TABLE 5A

SCHOOL PREPARATION FOR THE WORLD OF WORK

\begin{tabular}{|l|l|l|l|l|l|l|l|l|}
\hline \multirow{2}{*}{$\begin{array}{l}\text { School has adequately prepared } \\
\text { me for work }\end{array}$} & \multicolumn{2}{|c|}{ Agreed } & \multicolumn{2}{c|}{ Uncertain } & \multicolumn{2}{c|}{ Disagree } & \multicolumn{3}{c|}{ Total } \\
\cline { 2 - 10 } & No & & No & $\%$ & No & $\%$ & No & $\%$ \\
\hline Form 3 & 74 & 74 & 8 & 8 & 18 & 18 & 100 & 100 \\
\hline Form 5 & 54 & 54 & 15 & 15 & 31 & 31 & 100 & 100 \\
\hline
\end{tabular}

TABLE 5B

SCHOOL PREPARATION FOR THE WORLD OF WORK

\begin{tabular}{|l|c|c|c|c|c|c|c|c|}
\hline \multirow{2}{*}{$\begin{array}{l}\text { School has adequately prepared } \\
\text { me for work }\end{array}$} & \multicolumn{2}{|c|}{ Agree } & \multicolumn{2}{|c|}{ Uncertain } & \multicolumn{2}{c|}{ Disagreed } & \multicolumn{3}{c|}{ Total } \\
\cline { 2 - 9 } & No & $\%$ & No & $\%$ & No & $\%$ & No & $\%$ \\
\hline Location of school & & & & & & & & \\
\hline Gaborone & 65 & 65 & 12 & 12 & 23 & 23 & 100 & 100 \\
\hline Moshupa & 24 & 48 & 6 & 12 & 20 & 40 & 50 & 100 \\
\hline Lentsweletau & 38 & 76 & 5 & 10 & 7 & 14 & 50 & 100 \\
\hline Total & $\mathbf{1 2 7}$ & $\mathbf{6 3 . 5}$ & $\mathbf{2 3}$ & $\mathbf{1 1 . 5}$ & $\mathbf{2 5}$ & $\mathbf{2 0 0}$ & $\mathbf{2 0 0}$ & $\mathbf{2 0 0}$ \\
\hline
\end{tabular}

From the focus group discussions it became evident that some students already knew what careers to pursue. Their commitment to their chosen career paths was supported by their subject combinations, commitment to learning and determination to pass their examinations. Almost all of them were science students. These students were confident that they would pass their exams as they were serious about their studies. On the other hand, there were those students who appeared confident that school had provided them with enough information to be able to make informed career choices. They were optimistic that one way or the other they would pass their examinations. Lastly, there were those who had not yet decided on their future careers, and were uncertain how their education would help them. This is the group that felt that school had not provided them with adequate information to make informed career choices. These students seemed to be just drifting through school. They were not sure whether they would pass their examinations at the end of the year. In general, most of the respondents had no definite plans for the future. It seemed that they were missing the link between their current education and their future careers.

Data from the focus group discussions also show that secondary school leavers knew about the problem of unemployment. They indicated that they got the information from the media and that they see a lot of other youths who are out of school roaming the streets. What was evident from the discussions is that, even though the students knew about the problem of youth unemployment, they failed to associate themselves with it. They did not think of themselves becoming unemployed, even though a lot of them were not sure if they were going to pass their final examinations. On the issue of what they would do if they did not make it academically, many students were not sure, indicating that they had not really thought about it. Many of the males indicated that they may join either the police force or the army. This shows that a lot of 
them, especially the Form 3s, have not considered the minimum age requirement for entry, which is 18 years. Despite career guidance being offered in the schools, the data indicate that many of the respondents did not have any concrete career plans.

The data show that a considerable number $(77,38.5 \%)$ thought it would be easy to get a job after their studies, and $52(26 \%)$ indicated that they were uncertain. This may be partly due to the perception of the respondents that school has prepared them for work. It was also evident that the Form $3 \mathrm{~s}$ had not been adequately exposed to career-related information, the realities of the job market and what it takes to get a job. The data indicate that more than half of the Form $3 \mathrm{~s}$, compared to Form $5 \mathrm{~s}$, agreed that it would be easy to get a job.

\section{ATTITUDES TOWARDS MANUAL WORK}

The data indicate that, generally, the respondents have negative attitudes towards manual work. Different factors, but especially the negative characteristics of manual work, contribute to these negative attitudes. Many of the respondents note that they would rather remain unemployed than do jobs that pay "peanuts", have belittling names and offer no prospects for further studies. Overall, the Form $3 \mathrm{~s}$ seemed to have a more positive attitude towards manual work than the Form 5s (Table 6).

Table 6 presents data on the extent of agreement with unfavourable statements about manual work.

\section{TABLE 6}

EXTENT OF AGREEMENT WITH UNFAVOURABLE STATEMENTS

\begin{tabular}{|l|c|c|c|c|c|c|c|c|}
\hline \multirow{2}{*}{ Attitude Statement } & \multicolumn{2}{|c|}{ Agree \% } & \multicolumn{2}{c|}{$\begin{array}{c}\text { Uncertain } \\
\%\end{array}$} & \multicolumn{2}{|c|}{ Disagree \% } & \multicolumn{3}{c|}{ Total } \\
\cline { 2 - 10 } & No & $\%$ & No & $\%$ & No & $\%$ & No & $\%$ \\
\hline $\begin{array}{l}\text { Manual work is for people who } \\
\text { have failed in their studies }\end{array}$ & 38 & 19 & 41 & 20.5 & 121 & 60.5 & 200 & 100 \\
\hline Manual work is for minority tribes & 18 & 9 & 44 & 22 & 140 & 78 & 200 & 100 \\
\hline $\begin{array}{l}\text { Manual work is for males } \\
\text { Manual work has very long and } \\
\text { inflexible hours }\end{array}$ & 131 & 65.5 & 31 & 15.4 & 37 & 29 & 200 & 100 \\
\hline $\begin{array}{l}\text { Manual work involves a lot of } \\
\text { physical work and pays less }\end{array}$ & 139 & 69.5 & 28 & 14 & 33 & 16.5 & 200 & 100 \\
\hline $\begin{array}{l}\text { Manual work increases chances of } \\
\text { accidents/injury at work }\end{array}$ & 120 & 60 & 38 & 19 & 42 & 21 & 200 & 100 \\
\hline $\begin{array}{l}\text { With manual work one can be } \\
\text { expelled from work anytime }\end{array}$ & & 51 & 50 & 25 & 48 & 24 & 200 & 100 \\
\hline $\begin{array}{l}\text { Manual work has too much } \\
\text { supervision and too many rules } \\
\text { that change anytime }\end{array}$ & 106 & 53 & 52 & 26 & 41 & 21 & 200 & 100 \\
\hline
\end{tabular}


Positive attitudes towards manual work were expressed by 121 (60.5\%) respondents who disagreed that manual work is for people who have failed in their studies; $140(70 \%)$ disagreed that manual work is for minority tribes; and $158(79 \%)$ also disagreed that manual work is for males; 131 (65.5\%) agreed that manual work has very long and inflexible hours; 139 (69.5\%) agreed that it involves a lot of physical activity and pays less; 120 (60\%) agreed that it increases chances of accidents/injury at work; 102 (51\%) noted that one could be expelled from the job at anytime; and $106(53 \%)$ agreed that there is too much supervision and the rules can change without notice.

Table 7 shows that negative attitudes about doing manual work after school were reflected among slightly more than half of the respondents; $116(51 \%)$ respondents indicated that they would not consider engaging in manual work, while $27(13.5 \%)$ were uncertain. Only 57 $(28.5 \%)$ agreed that they are more likely to engage in manual work after completing school. Gender differences were reflected by $39 \%$ of males as compared to $18 \%$ of females who said they would consider engaging in manual work. Thus $64 \%$ of females and $52 \%$ of males would not engage in manual work after completing their studies. Gender difference may be partially attributed to the general perception that women are not suitable for manual work. Since the respondents' main focus at the time of the study might have been on the examinations, doing manual jobs might have been far from their minds. The majority of students in Gaborone (61\%) and Moshupa (76\%) noted that they are more unlikely to engage in manual work after completing their studies. However, $48 \%$ of respondents in Lentsweletau agreed that there are more likely to engage in manual work after completing school, while $34 \%$ disagreed.

TABLE 7

\section{LIKELIHOOD OF RESPONDENTS ENGAGING IN MANUAL WORK AFTER COMPLETING STUDIES}

\begin{tabular}{|c|c|c|c|c|c|c|c|c|}
\hline \multirow[t]{2}{*}{ Attitude Statement } & \multicolumn{2}{|c|}{ Agree \% } & \multicolumn{2}{|c|}{ Uncertain \% } & \multicolumn{2}{|c|}{ Disagree \% } & \multicolumn{2}{|c|}{ Total } \\
\hline & No & $\%$ & No & $\%$ & No & $\%$ & No & $\%$ \\
\hline \multicolumn{9}{|l|}{ Gender } \\
\hline Male & 39 & 39 & 9 & 9 & 52 & 52 & 100 & 100 \\
\hline \multirow[t]{2}{*}{ Female } & 18 & 18 & 18 & 18 & 64 & 64 & 100 & 100 \\
\hline & 57 & 57 & 27 & 27 & 116 & 116 & 200 & 100 \\
\hline \multicolumn{9}{|l|}{ Form } \\
\hline Form 3 & 44 & 44 & 116 & 16 & 40 & 40 & 100 & 100 \\
\hline \multirow[t]{2}{*}{ Form 5} & 13 & 13 & 11 & 11 & 76 & 76 & 100 & 100 \\
\hline & 57 & 57 & 27 & 27 & 116 & 116 & 200 & 100 \\
\hline \multicolumn{9}{|l|}{ Location } \\
\hline Gaborone & 26 & 26 & 13 & 13 & 62 & 61 & 100 & 100 \\
\hline Moshupa & 7 & 14 & 5 & 10 & 38 & 76 & 50 & 100 \\
\hline \multirow[t]{2}{*}{ Lentsweletau } & 24 & 48 & 9 & 18 & 17 & 34 & 50 & 100 \\
\hline & 57 & 28.5 & 27 & 13.5 & 11.6 & 58 & 200 & 100 \\
\hline
\end{tabular}


TABLE 8

EXTENT OF AGREEMENT WITH FAVOURABLE STATEMENT

\begin{tabular}{|l|c|c|c|c|c|c|c|c|c|}
\hline \multirow{2}{*}{ Attitude statement } & \multicolumn{2}{|c|}{ Agree } & \multicolumn{2}{|c|}{ Uncertain } & \multicolumn{2}{c|}{ Disagree } & \multicolumn{2}{c|}{ Total } \\
\cline { 2 - 10 } & No & $\%$ & No & $\%$ & No & $\%$ & No & $\%$ \\
\hline $\begin{array}{l}\text { I would consider engaging in manual work as } \\
\text { first choice after completing my studies }\end{array}$ & 57 & 28.5 & 27 & 13.5 & 116 & 58 & 200 & 100 \\
\hline $\begin{array}{l}\text { I would do manual work temporarily while I } \\
\text { look for a suitable job }\end{array}$ & 47 & 38 & 19 & 68 & 34 & 200 & 100 \\
\hline $\begin{array}{l}\text { Doing manual work allows workers to } \\
\text { participate in decision making }\end{array}$ & 124 & 62 & 16 & 8 & 60 & 30 & 200 & 100 \\
\hline $\begin{array}{l}\text { Manual work is respected and has social } \\
\text { recognition }\end{array}$ & 62 & 31 & 34 & 17 & 104 & 52 & 200 & 100 \\
\hline
\end{tabular}

Table 8 presents data on how respondents viewed manual work. Positive attitudes were expressed by 124 (62\%) respondents, who noted that doing manual work was better than being unemployed; 94 (47\%) noted that they would do manual work temporarily while looking for a suitable job. However, negative attitudes were expressed by 116 (58\%) respondents who disagreed that they would consider engaging in manual work after completing their studies; and $68(34 \%)$ also indicated that they would not engage in manual work temporarily while looking for a suitable job. Negative attitudes were further expressed by 104 (52\%) respondents, who pointed out that manual work is not respected and has no social recognition. In terms of educational level, more Form 3s (58\%) than Form 5s (36\%) showed a positive attitude towards manual work by agreeing that they would consider doing manual work temporarily while looking for a suitable job.

TABLE 9

MANUAL WORK IS RESPECTED AND HAS SOCIAL RECOGNITION

\begin{tabular}{|l|c|c|c|c|c|c|c|c|}
\hline \multirow{2}{*}{ Form } & \multicolumn{2}{|c|}{ Agree } & \multicolumn{2}{c|}{ Uncertain } & \multicolumn{2}{c|}{ Disagree } & \multicolumn{2}{c|}{ Total } \\
\cline { 2 - 10 } & No & $\%$ & No & $\%$ & No & $\%$ & No & $\%$ \\
\hline Form Three & 43 & 43 & 20 & 20 & 36 & 36 & 100 & 100 \\
\hline Form Five & 19 & 19 & 14 & 14 & 67 & 67 & 100 & 100 \\
\hline Total & $\mathbf{6 2}$ & $\mathbf{3 1}$ & $\mathbf{3 4}$ & $\mathbf{1 7 . 0}$ & $\mathbf{1 0 4}$ & $\mathbf{5 2}$ & $\mathbf{2 0 0}$ & $\mathbf{1 0 0}$ \\
\hline
\end{tabular}

Table 9 shows that a large number of Form 5s (67\%), compared to Form 3s (36\%), disagreed that manual work is respected and has social recognition. More Form 3s (20\%) than Form 5s (14\%) were uncertain, while more Form 3s (43\%) than Form 5s (19\%), agreed that manual work is respected and has social recognition. Respondents in the focus groups noted that manual work is not for minority tribes or those who have failed in their studies, even though most of them are found in such jobs.

\section{EMERGING ISSUES}

\section{CAREER- AND JOB-RELATED ISSUES}

What emerges from the data is that the majority of the respondents know that youth unemployment is a problem in Botswana. However, they seem to detach themselves from it. Most of them do not think of what will happen to them after they complete their current level of studies, especially if they do not pass their examinations. All of them aspire to a future career. 
However, many of them would not achieve the desired careers. This is because they prefer white collar jobs, for which they are not qualified, as opposed to manual work. The respondents want jobs that pay well and confer status. They would work for a better salary more than for anything else. However, good pay usually comes with a high qualification and years of experience, which the respondents do not have. Furthermore, respondents feel that school has prepared them adequately for the world of work, and therefore hope that they would easily find jobs after leaving school. This is in sharp contrast with the reality on the ground. Many of the students would not pass their examinations, or find white-collar jobs at the end of their studies, and if they do find white-collar jobs, they would have to start from the bottom. Thus they will not have the status and high salaries they aspire to.

\section{ATTITUDES TOWARDS MANUAL WORK}

Some respondents expressed positive attitudes to a certain extent when they noted that they would consider engaging in manual work temporarily while they look for a suitable job. The majority of those who indicated that they would consider manual work were males. Respondents further indicated that manual work is better than being unemployed. Generally, however, negative attitudes were expressed towards manual work. Reasons for the negative attitude to manual work emanated from the fact that it is not respected and has a low social status. The majority of the respondents indicated that they would not do manual work because it is looked down upon. Other reasons given were that manual work has very long inflexible hours; involves a lot of physical work; pays less; has too much supervision and too many rules that change anytime; increases chances of accidents and injury at work; is often dull and monotonous; does not give workers the opportunity to be creative and innovative; and does not offer self-improvement through further studies. Because of these and other factors many of the respondents would rather stay unemployed than engage in manual work.

The society plays a very important role in shaping the attitudes of the youth (secondary school leavers). Hence to change students' attitudes towards manual work, it is very important that societal attitudes are also addressed. This is because young people are influenced by the values and attitudes that are upheld in society. To kick-start a campaign on changing societal attitudes towards manual work, the media, as a powerful agent of change, must play an important role. The media should promote manual work by presenting it as a viable form of employment, especially for new entrants to the labour market with low levels of education and with little or no experience.

Other stakeholders too should be involved in the promotion of the status of manual work. These include the society at large, parents, youth organisations, social workers, employers and the government through the relevant ministries. The government, as the main employer, should review the minimum wage to make it more attractive to job seekers. Employers in the manual work sector should improve the image of manual work by addressing the negative aspects that contribute to its low social status; review salaries of manual workers; reduce long working hours; and generally improve the working conditions of their employees. School career guidance and counselling teachers and social workers should seriously engage school leavers on issues related to subject selections in school, the functioning and requirements of the labour market, students' adaptability to economic factors, and generally preparing students for the future. In the light of the range and complexity of factors which influence student attitudes and motivation towards preparing for their future, it is clearly time to develop an integrated approach to counselling that supports students in the development of their post-school options. The approach should focus on the educational and motivational needs of students, and the 
training options available to them. This could also involve industrial placements for students to give them some experience of the world of work.

School leavers' perceptions of the world of work indicate that a lot needs to be done with regards to career guidance. Students need to come to terms with the realities of the labour market, such as the need for specialised qualifications, experience and, most importantly, the age factor. These must be presented to the students in a way that makes sense to them and with which they can identify. Secondary school leavers' ages range from 15 to 20, which means most of them are too young, especially the Form $3 \mathrm{~s}$, to enter the labour market. The age factor also disadvantages them when it comes to manual work, because of the physical nature of the activities involved.

\section{CONCLUSION}

Most of the secondary school leavers acknowledged that doing manual work is better than being unemployed, but it seems that it is better for people other than themselves. Considering the fact that this age group is the most affected by the problem of unemployment in Botswana, their attitude towards manual work, which potentially can be their main source of employment, is problematic. Therefore, in order to make it attractive to youths, there is an urgent need to create a new frame of reference for manual work. Furthermore, students need to learn to think about the future; recognise their responsibility for educational planning; broaden their aspirations beyond the stereotypes of gender roles; consider other employment routes/career options; and develop the ability to adapt to changing times. Students need to understand how school relates to future life goals, and recognise the broad scope of the world of work and their potential place in it. Social workers can play a key role in all this, together with teachers, to help students make flexible, realistic and long-range career plans. This may help them prepare for jobs other than white-collar work, especially if they fail to make it academically. It may also help reduce the negative perception about certain jobs, and enable them to choose jobs according to the circumstances they find themselves in, if they cannot get their preferred jobs.

\section{REFERENCES}

AJZEN, A. \& FISHBEIN, M. 1980. Understanding attitudes and predicting social behaviour. New Jersey: Prentice Hall.

AUSTRALIAN NATIONAL BOARD OF EMPLOYMENT, EDUCATION AND TRAINING. 1995. Students' attitudes towards careers and post school options for education, training and employment. Canberra: Australian Government Publishing service.

BENDER, S. 1994. Female students career aspirations in Science. SSTA Research Center. [Online] Available: http://www.ssta.sk.ca/tesearch/education_equity/94-04.html. [Accessed: 10/10/2006].

BERGMANN, H. 2002. Practical subjects in basic education - relevance at last or second rate education. Eschborn: Sustainable Development Department.

BNET. 2010. [Online] Available: dictionary.bnet.com/definition/manual+worker.html. [Accessed: 10/03/2010].

CALVES, A.E. \& SCHOUMAKER, B. 2004. Meeting youth unemployment head on. [Online] Available: www.uneca.org/era2005/chapter5.pdf. [Accessed: 20/07/2006].

CENTRAL STATISTICS OFFICE. 2008. 2005/06 Labour Force Report. Gaborone: Department of Printing and Publishing Services. 
CLARK, M. \& PAGE, C. 2002. Gender and the changing division of labour. [Online] Available: http://www.education.tas.gov.au/equitystandards/gender/framewrk/pathways.htm. [Accessed: 22/07/2006].

DAILY NEWS ONLINE, 7 February 2003. MP Affirms Batswana are Lazy. [Online] Available: http://www.gov.bw/cgi-bin/news.cgi?d=20030207. [Accessed: 10/04/2005].

FISHBEIN, M. \& AJZEN, I. 1975. Belief, attitude, intention and behavior. Reading, M.A. Addison: Wesley.

GOVERNMENT OF BOTSWANA. 2001a. Botswana Household Income and Expenditure Survey. 2002/3 Statistical Brief. Central statistics Office. [Online] Available: www.cso.gov.bw.cso. [Accessed: 17/01/2008].

GOVERNMENT OF BOTSWANA 2001b. Botswana Population and Housing Dissemination seminar. Gaborone Government Printer.

HALE, J.L., HOUSEHOLDER, B.J. \& Greene, K.L. 2003. The theory of reasoned action. In: DILLARD, J.P. \& PFAU, M. (eds) The persuasion handbook: developments in theory and practice. Thousand Oaks, CA: Sage Publications.

HELPR SYSTEM. 2004. Why people work. [Online] Available: http://www.horizons helpr.org/english/whywork/handout3.pdf. [Accessed: 05/03/2006].

HILL, R.B. 1996. Historical context of the work ethic. Department of Occupational Studies. Athens: University of Georgia.

INTERNATIONAL LABOUR ORGANIZATION (ILO). 2004. Youth unemployment at all time high. [Online] Available: http://www.ilo.org/public/english/employment/strat/download/ getyen.pdf.

INTERNATIONAL LABOUR ORGANIZATION (ILO). 2008. Global Employment Trends for Youth October 2008. Geneva: International Labour Office,

INTERNATIONAL LABOUR ORGANIZATION (ILO). 2009. Global Employment Trends 2009. Geneva: International Labour Office.

KARLSEN, U.D. 2001. Some things never change: youth and occupational preferences. Acta Sociological Journal, 44:242-255.

KIURANOV, C. 1982. Attitude of youth to work: the Bulgarian case: Sofia: Ohridsky University.

LAUGHLIN, C. \& BARLIN, J. 2001. Young workers' work values, attitudes, and behaviours. Journal of Occupational and Organisational Psychology, 74(4):543-558.

LEWIS, R. 1992. Finn. Carmichael and a more compliant work force. [Online] Available: Green left weekly home page. Greenleft.org. [Accessed: 10/01/2006].

LLOYD, T. 1999. Young men's attitudes to gender and work. London: Joseph Rowntree Foundation.

MELZER, S. 2003. Data compares blue collar workers and white collar workers. Urek Alert. [Online] Available: http://wwweurekalert.org/pub_releases/2003-4/uoc_uss040303.php. [Accessed: 04/03/2004].

MILLER, K. 2005. Communications theories: perspectives, processes and context. New York: McGraw Hill. 
MORRIS, C.G. \& MAISTO, A.A. 2001. Understanding Psychology ( $5^{\text {th }}$ ed). New Jersey: Prentice Hall.

MUKAMUGAMBIRA, P. \& OSEI-HWEDIE, K. 2007. Factors influencing attitudes of Botswana youth towards manual work: implications for employment. Journal of Social Development in Africa, 22(2):106-136.

OSEI-HWEDIE, K., MUFUNE, P. \& MWANSA, L.K. 1991. Work attitudes and life goals of Zambian youth. Journal of Social Development in Africa, 6(1):63-73.

ROMO, H.D. 1998. Latina High School leaving: some practical solutions. ERIC Digest. [Online] Available: http://www.ericfacility.net/databasee/ERIC_Digests/ed423095.htl. [Accessed: 05/04/2005].

SIPHAMBE, H.K. 2003. Economic activity and labour force. 2001 population and Housing Census Dissemination Seminar 2003. Gaborone: Government Printers.

SKANS, O.N. 2004. Scarring effects of the first labour market experience: a sibling based analysis. Institute for Labour Market Policy Evaluation. Swedish Ministry of Education. [Online] Available: http://www.ifau.se/upload/pdf/se/2004/wp04-14.pdf. [Accessed: 10/01/2005].

SMITH, S. 2002. Occupational hazards. London: Penton Media Inc.

SOCIETY FOR INTEGRATED DEVELOPMENT OF HIMALAYAS (SIDH). 2000. A matter of quality: a study of people's perceptions and expectations from schooling in rural areas of Uttarakhand. Mussoorie: Sanshodhan Research and Advocacy Wing.

THE VOICE NEWSPAPER. 2007. Did do better: 2006 BGCSE results show marked improvement, $23^{\text {rd }}$ February.

TOURAINE, A. 1991. Young people and unemployment around the world. Paris: Orient Longman.

UNITED NATIONS ECONOMIC COMMISSION FOR AFRICA (UNECA). 2002. Youth and employment in the ECA Region. Youth Employment Summit. Alexandria, Egypt, September 7-11.

VERMA, R. 2004. Half the world's jobless are youth. One world South Asia. [Online] Available: OneWorld.Net. [Accessed: 02/07/2005].

Professor Kwaku Osei-Hwedie, Ms Diana Kgwatalala, Department of Social Work, University of Botswana, Gaborone. 